\title{
Revisiting the Role and Future of National Constitutions in European and Global Governance: Introduction to the Research Project
}

\author{
Anneli Albi and Samo Bardutzky
}

\begin{abstract}
The Introduction provides an overview of the research project 'The Role and Future of National Constitutions in European and Global Governance', which was funded by a five-year grant of 1.2 million EUR, awarded by the European Research Council (ERC). The research findings are published in the present two-volume book, containing national reports from twenty-eight EU Member States, and a twenty-ninth report - focusing on constitutional reforms related to global governance - from Switzerland. The reports are based on the project Questionnaire. The main themes are threefold: (a) constitutional amendments with a view to EU membership; (b) constitutional adjudication at the national level regarding EU measures such as the Data Retention Directive, European Arrest Warrant and ESM Treaty; and (c) novel challenges that are increasingly highlighted in the wider context of global governance (i.e. beyond the classic international treaties that advance human rights, peace and environmental protection) in relation to democratic participation, judicial review and the rule of law. Whilst in the mainstream discourse national constitutions have typically
\end{abstract}

Anneli Albi is Professor of European Law, University of Kent, United Kingdom. e-mail: A.Albi@kent.ac.uk.

Samo Bardutzky is Assistant Professor of Constitutional Law at the University of Ljubljana, Slovenia; at the time of writing Research Associate, University of Kent, United Kingdom. e-mail: samo.bardutzky@pf.uni-lj.si.

The introductory chapter to the book was prepared as part of the research project 'The Role and Future of National Constitutions in European and Global Governance', funded by European Research Council (ERC) grant No. 284316 (Project acronym: ConstEurGlobGov). The views are solely those of the authors, and cannot be attributed to the ERC or to the European Union. We would like to thank linguistic editor Siiri Aulik for her helpful assistance and comments. However, the views and any errors are solely those of the authors. Updates regarding the research project are available on the project website https://research.kent.ac.uk/roc/.

All websites noted in the Introduction were accessed on 21 March 2018.

\author{
A. Albi $(\bowtie)$ \\ Law School, University of Kent, Canterbury, UK \\ e-mail: A.Albi@kent.ac.uk \\ S. Bardutzky \\ University of Ljubljana, Ljubljana, Slovenia \\ e-mail: samo.bardutzky@pf.uni-lj.si
}


been approached from a top-down perspective and with a focus on sovereignty, the present bottom-up study allows for the perspective to be broadened by looking at how EU and transnational law have affected constitutional cultures in specific areas, such as fundamental rights protection, rule of law safeguards and constitutional review. The reports are accompanied by a linked book with a Comparative Study, which divides the constitutional systems of the EU Member States into three broader constitutional cultures and identifies overarching trends, changes and processes regarding constitutionalism. The comparative research findings are briefly outlined in the Introduction, inviting discussion on what ought to be the direction of travel for national, comparative European, EU and global constitutionalism. The project and the reports explore constitutional developments up until 2014-15 and do not address the more recent illiberal trends.

Keywords Comparative constitutional law and comparative European constitutional achievements - Political, post-totalitarian and traditional legal constitutions Constitutional amendments regarding EU integration · Fundamental/constitutional rights - The rule of law and the social democratic Rechtsstaat - European Arrest Warrant • Data Retention Directive · ESM Treaty, euro crisis, mutualisation of debt and democracy $\cdot$ Autonomous EU and global constitutionalism The governance paradigm and neofunctionalism - Changing language of constitutionalism at the transnational level - Uniformity and diversity

\section{The Reasons for Revisiting the Role of the National Constitutions}

We are delighted to bring to the readers what in our view is a truly fascinating book, National Constitutions in European and Global Governance: Democracy, Rights, the Rule of Law - National Reports, with two combined volumes containing twenty-nine national reports, and which will shortly be accompanied by a linked comparative monograph that is hereinafter referred to as the 'Comparative Study'. With the important transformations in the discourse on EU and global constitutionalism over the last few decades, we consider this to be an opportune moment to take a step back and revisit what is, or ought to be, the role of national constitutions in the new transnational legal environment. Indeed, the book comes at a time when both the European Union and the broader discourse on constitutionalism are at crossroads, with many important questions about their future directions at the centre of discussions.

Before the euro crisis, on the broader level of global constitutionalism, one leading scholarly article summarised the ongoing processes - primarily in relation to democratic legitimacy - as 'the end of constitutionalism as we know it'. ${ }^{2}$ Another book brought together leading scholars of constitutional theory to examine issues

\footnotetext{
${ }^{1}$ For the publication details of the Comparative Study, see below the text accompanying note 44 .

${ }^{2}$ Kuo 2010.
} 
relating to what in the title was rhetorically phrased as 'The twilight of constitutionalism?' ${ }^{3}$ Some scholars have additionally noted the emergence of a thin, weak, procedural version of the rule of law, judicial review and democratic control in the context of European and global economic co-operation, with reduced opportunities for citizens to challenge public decisions. ${ }^{4}$ Furthermore, the extent to which the vocabulary of constitutionalism may have changed emerges from a recent influential monograph, Beyond Constitutionalism, by Nico Krisch, who calls for breaking away from and discarding the paradigm of constitutionalism in post-national law altogether, in favour of a paradigm of pluralism. ${ }^{5}$ Krisch has summarised what seems to be the prevailing view amongst EU and global governance lawyers: 'the prospect of domestic constitutionalism shaping global governance or controlling its impact is very limited', and the only hope would be 'to turn the clock back and begin to withdraw from regional and international structures of cooperation'. ${ }^{6}$

An increasing number of scholars have begun to express heightened concerns about the decline of constitutionalism in the context of the euro crisis management. For example, Agustín Menéndez has documented the breadth of the European Union's 'constitutional mutation', ${ }^{7}$ warning that 'the breakdown of constitutional law will result in the mid- or long-run in the breakdown of the Social and Democratic Rechtsstaat'. ${ }^{8}$ Gunnar Beck cautions that the recent euro crisis adjudication in the European and national courts has allowed a bending of the rules to suit the executive to the extent that 'the Rechtsstaat is effectively suspended'. ${ }^{9}$ The prevailing theories in Italy, as summarised by Andrea Simoncini, are that the euro crisis measures have accelerated a 'decline of European constitutionalism', with constitutions 'destined to be obsolete' in 'the present age [that is] no longer the age of constitutions'. ${ }^{10}$ A small but growing number of scholars have even expressed concern about the EU having taken an authoritarian turn in the euro crisis governance. Christian Joerges and Maria Weimer have cautioned against the entrenchment of 'authoritarian executive managerialism'11 that 'threatens to discredit the idea of the rule of law and its intrinsic linkages to democratic rule'. ${ }^{12}$ Alexander Somek finds that in the EU's euro crisis management, 'formal legal constraints are bent in order to accommodate necessities'; he is concerned that this has led to

\footnotetext{
${ }^{3}$ Dobner and Loughlin 2010, p. xi.

${ }^{4}$ Harlow 2006, p. 195; Galera 2010, p. 302.

${ }^{5}$ Krisch 2010, pp. 21, 26, 79, 303. On the changing vocabulary of constitutionalism, see Martinico 2015 , pp. 5 et seq., and below notes 74 and 92 , along with the accompanying text.

${ }^{6}$ Krisch 2010, pp. 20-21.

${ }^{7}$ Menéndez 2014.

${ }^{8}$ Menéndez 2013, pp. 522-533, quote at p. 523.

${ }^{9}$ Beck 2012, pp. 446-449, as cited in Bobek 2014, p. 423.

${ }^{10}$ Simoncini 2013, pp. 158-159, 186.

${ }^{11}$ Joerges and Weimer 2012.

12 Joerges 2014, p. 26.
} 
'authoritarian liberalism' and 'loss of political agency', with the executive branch gaining power, as the constraints on governance are economic. ${ }^{13}$ Michael Wilkinson, also describing the EU crisis governance as 'authoritarian liberalism', has observed a process of 'de-democratisation', 'de-legalisation' and the overriding of Europe's constitutional law with market teleology. ${ }^{14}$

However, what has hitherto received negligible attention is the way in which European constitutionalism and the European constitutional law discourse had already changed in the years preceding the financial crisis, during the 'state of normalcy'. In particular, two key EU measures - the European Arrest Warrant Framework Decision ${ }^{15}$ and the (eventually annulled) Data Retention Directive ${ }^{16}$ are emblematic of broader changes in fundamental rights protection, constitutional review and judicial practice. In the following paragraphs, we will bring some examples of the issues explored in the national reports in the present two-volume book and in the accompanying Comparative Study. We consider the quotes cited to be both disconcerting - as they signal an uncertain fate for some of the historical achievements of European constitutionalism - as well as motivating for lawyers and scholars who may have had concerns about strain on well-established fundamental rights and values within individual national constitutional orders but without awareness that such concerns are often more widely shared.

By way of such examples, with regard to the European Arrest Warrant (EAW), the Italian report poignantly documents the way in which the national legislature was caught between criticism regarding infringements of fundamental rights in the context of the EAW and pressure from the European Commission, which was relentless in its calls for a faithful and complete implementation of the controversial Framework Decision. The report summarises concerns articulated by governmental committees and numerous legal scholars in Italy. Among the latter, the eminent constitutionalist Cesare Pinelli characterised the EAW as 'the first serious threat of disablement of the constitutional guarantees to the right of liberty'. ${ }^{17}$ In Ireland, the automaticity involved in giving effect to foreign prosecutorial and judicial decisions has been a constant source of concern for the Irish courts, which the Irish report extensively documents with examples from case law. ${ }^{18}$ In Slovenia, scholarship has

\footnotetext{
${ }^{13}$ Somek 2014, pp. 23-24.

${ }^{14}$ Wilkinson 2016, pp. 29 et seq.

${ }^{15}$ Council Framework Decision of 13 June 2002 on the European arrest warrant and the surrender procedures between Member States (2002/584/JHA), [2002] OJ L 190/1.

${ }^{16}$ Directive 2006/24/EC of the European Parliament and of the Council of 15 March 2006 on the retention of data generated or processed in connection with the provision of publicly available electronic communications services or of public communications networks and amending Directive 2002/58/EC, [2006] OJ L 105/54.

${ }^{17}$ Pinelli 2012, p. 2399, as cited in the report on Italy by Martinico, Guastaferro and Pollicino in this book [The Constitution of Italy: Axiological Continuity Between the Domestic and International Levels of Governance?], Sect. 2.3.5.1.

${ }^{18}$ The report on Ireland by Hogan in this book [Ireland: The Constitution of Ireland and EU Law: The Complex Constitutional Debates of a Small Country], Sects. 2.3.1.1 and 2.3.6.
} 
warned that the "uncritical application of the principle of mutual recognition bears the danger of transforming the judge into a kind of a "ticking box" automaton checking only pre-established criteria and neglecting his/her duty of a critical assessment and safeguarding fundamental (constitutional) rights to the defendant'. ${ }^{19}$ From the Netherlands, concerns expressed by Judge Rob Blekxtoon from the District Court of Amsterdam are summarised in the accompanying Comparative Study. Judge Blekxtoon has written that his 'quiet life was disturbed' and he 'began writing critical articles on the European Arrest Warrant in various journals and law reviews', and that he even took the initiative in 2005 to publish the Handbook on the European Arrest Warrant in his effort to save 'the well-established principles of extradition law which serve to safeguard the interests of the requested persons'. ${ }^{20}$ Judge Blekxtoon additionally wrote that he was 'very disappointed', as he had been 'told by people closely following the drafting of the EAW Framework Decision that the officials responsible for the outcome did not really want to listen to the experts present at the negotiations who knew what they were talking about'. It had been 'more important to speed up matters for political reasons'. ${ }^{21}$

Turning to the Data Retention Directive, the Austrian report spells out a concern that also implicitly arises from several other reports - that a 'taboo' has been 'broken':

... Austrian society and the state did everything to escape this unconstitutional situation and finally succeeded. The damage, however, was already done. The taboo was broken and since [... the annulment of the Directive], Austrian police authorities have increased political pressure for re-implementation. ${ }^{22}$

The Slovenian report notes that if the Data Retention Directive

had been a purely domestic legislative project, it would have probably met insurmountable constitutional and democratic obstacles. But as it originated in the EU, it became part of the law in a very different atmosphere. ${ }^{23}$

Along with the above measures, the present edited volume predominantly focuses on the constitutional impact of the pre-financial crisis developments and the question of what is, or ought to be, the normal state of affairs in European constitutionalism.

It should be noted early on that the project and the reports explore constitutional developments up until 2014-15 and do not address Brexit or the more recent illiberal trends. The timeline of the project is explained below in Sect. 5 .

\footnotetext{
${ }^{19}$ Erbežnik 2014, p. 131, as cited in the report on Slovenia by Bardutzky in this book [The Future Mandate of the Constitution of Slovenia: A Potent Tradition Under Strain], Sect. 2.3.5.3.

${ }^{20}$ Blekxtoon 2009, p. V.

21 Ibid., p. V.

22 The report on Austria by Lachmayer in this book [The Constitution of Austria in International Constitutional Networks: Pluralism, Dialogues and Diversity], Sect. 2.12.

${ }^{23}$ The report on Slovenia by Bardutzky in this book [The Future Mandate of the Constitution of Slovenia: A Potent Tradition Under Strain], Sect. 2.13.
} 


\section{Overview of the ERC-Funded Research Project 'The Role and Future of National Constitutions in European and Global Governance'}

The issues explored in the previous section are at the centre of the large-scale research project 'The Role and Future of National Constitutions in European and Global Governance'. The research project was funded by a five-year grant of 1.2 million EUR, awarded by the European Research Council (ERC) (Grant Agreement No. 284316; project acronym: ConstEurGlobGov), as part of the EU's Seventh Framework Programme.

The present two-volume book contains the first main aspect of the research: the twenty-nine national reports prepared by leading constitutional law experts. The national reports were written on the basis of a Questionnaire, which was prepared by Professor Anneli Albi, the Principal Investigator of the research project, in consultation with Dr Samo Bardutzky, who worked for several years as the project's Research Associate. The two volumes are accompanied by a linked, complementary book containing a Comparative Study. These aspects of the research project will be outlined in greater detail here and in the subsequent sections.

In designing the project's Questionnaire and thereby also the general framework of the national reports, the idea was to bring together case law, doctrine and constitutional debates from the perspective of a multitude of national constitutional systems. We sought to provide viewpoints from national and comparative constitutional law in order to offer a fuller understanding of European constitutional law than what has prevailed in the mainstream English language European constitutional discourse, where the starting point has typically been the autonomous nature of EU constitutional law and its top-down reception in the Member States. Additionally, whilst existing comparative studies are typically based on a limited number of case studies, we committed to covering all of the twenty-eight Member States of the Union, and added a twenty-ninth report - focusing on constitutional reforms related to global governance - from Switzerland. The inclusion of smaller and what are often regarded as more peripheral countries has not only allowed the project to give a greater voice and visibility to the diverse constitutional systems, but has also unearthed numerous interesting and important broader trends, patterns and changes that warrant wider attention and discussion. Some of these will be summarised at the end of this introductory chapter.

The editors would like to express their greatest gratitude for the generous grant funding from the ERC, which has made it possible to carry out such comprehensive and systematic research on comparative constitutional law that otherwise quite possibly would never have been brought to life. The views and any errors are solely those of the editors and authors, and cannot be attributed to the European Research Council or to the European Union.

We are also pleased that this book has been published by T.M.C. Asser Press, which has a long-established tradition of publishing in the field of interaction between EU law and national legal systems. One key Asser Press book that has 
become part of a well-established canon in the field is the so-called 'Red Book', The Constitutional Impact of EU Enlargement at EU and National Level, which explores how national constitutions both in the older and new Member States have been adjusted to accommodate EU membership. ${ }^{24}$ Another leading Asser Press publication that sparked interest in the research that follows is the above-mentioned Handbook on the European Arrest Warrant, edited by Judge Blekxtoon. ${ }^{25}$

\section{The Questionnaire}

The national reports have been structured and written on the basis of the above-mentioned Questionnaire, which is reproduced in the next chapter. The Questionnaire invited constitutional law experts to consider national case law, doctrine and policy documents in three main areas, and was divided into three parts.

Part 1 explored how constitutions reflect the transfer of powers from domestic to European and global institutions, and thus to what extent they provide legitimacy to the shift in the exercise of power to the transnational level and retain their social relevance. Part 2 of the Questionnaire looked beyond the question of transfer of sovereignty, which has been the predominant focus of the discourse so far, and asked for reflection on constitutional values that have a continued importance in the contemporary globalising and pluralist legal setting, such as the protection of fundamental rights, the rule of law and constitutional review. The experts were tasked with outlining constitutional court judgments that tackle the protection of these rights and values in transnational judicial dialogues, e.g. regarding the Data Retention Directive, the European Arrest Warrant, the Treaty Establishing the European Stability Mechanism (ESM Treaty) and European Commission and International Monetary Fund (IMF) economic crisis/austerity measures. The Questionnaire also invited assessment of the responsiveness of the European Court of Justice (CJEU) with regard to these rights and values, as well as assessment of the standard of protection at supranational level. Finally, Part 3 sought to explore the novel challenges that are increasingly highlighted in the wider context of global governance (i.e. beyond the classic international treaties that advance human rights, peace and environmental protection) in relation to legitimacy, democratic control, accountability and the rule of law.

It should be noted that the Questionnaire was prepared in 2013-2014 when critical scholarly and public discussion about EU and transnational governance was rare and very limited.

\footnotetext{
${ }^{24}$ Kellermann et al. 2001.

${ }^{25}$ Blekxtoon 2005; cf. also Blekxtoon 2009, p. V, supra n. 20 and the accompanying text.
} 


\section{The Constitutional Law Experts}

The constitutional experts from whom the reports were commissioned are leading scholars in the field of constitutional law or European constitutional law, with an extensive record of publications in the field of interaction between national and EU constitutional law (in English, given the overall nature of the book, which inevitably had to take priority over our commitment to bring other voices and languages to the fore). In some countries, two experts were invited as joint experts, while in other cases, the main constitutional expert opted to invite one or more research collaborators, given the extensive scope of the Questionnaire. In particular, we are pleased that several scholars specialising in the field of criminal law kindly joined the project to cover the questions relating to the European Arrest Warrant. The main constitutional experts are listed in the Preface. We are honoured that a number of distinguished, current and former judges of constitutional courts and other highest courts have joined us here as scholarly colleagues. In the intervening years, we were honoured to observe that several colleagues were subsequently appointed as Judge or Advocate General to the European Court of Justice. The editors are delighted to be able to present the full, collected reports which, thanks to countless hours of thorough, patient and perceptive research by more than sixty colleagues, make for rich and thought-provoking reading.

In the framework of the project, the Network of Constitutional Experts was established in the hope that it would provide a more long-term structure and forum for deliberating perspectives from comparative constitutional law in the context of transnational governance.

The project questions and draft reports were discussed at a work-in-progress seminar 'Assessing the Responsiveness of the EU to Constitutional Rights: Data Retention, Arrest Warrants and Beyond', held at the University of Kent on 28-29 August 2014. In addition to contributions from project experts, we were honoured to have presentations from a number of guest speakers who are distinguished judges and/or scholars working in related areas. The themes covered included: cases regarding the EU Data Retention Directive (Brun-Otto Bryde, Jiři Zemanek and Gerard Hogan); case law on social rights affected by the IMF austerity measures (Kristīne Krūma); the EU's democratic responsiveness (Damian Chalmers); the shift towards authoritarian executive managerialism in euro crisis governance (Christian Joerges); rights protection issues in the context of the European Arrest Warrant (Valsamis Mitsilegas, Esther Herlin-Karnell); and the constitutional issues surrounding the Trans-Atlantic Trade and Investment Partnership (TTIP) (Harm Schepel). 


\section{The National Reports and the Timeline of the Project}

The structure of the national reports follows the three parts of the Questionnaire. ${ }^{26}$ In principle, the authors were expected to follow the numbering of the questions from the Questionnaire, so that the reader would be able to compare the situation in a number of jurisdictions regarding a particular issue. To a great extent, this is indeed the case. Nevertheless, as the accounts of the individual constitutional systems differ, the editors did not insist on the numbering and, in many instances, the answers to questions have been merged. In the editorial process, we aimed to ensure that the reports would, as far as possible, be written in a way that would allow for them to be read independently without reference to the Questionnaire.

Whilst the reports are relatively lengthy - in the range of 19,000-23,000 words they are also simultaneously not long enough, as they essentially provide but a glimpse of both the constitutional culture as well as of the constitutional doctrine and debates in the individual areas explored. Experts were not expected to answer all of the questions in an equal level of detail; they were invited to focus on issues of particular relevance for the Member State in question. Where the national discussions were considered particularly to be of broader, Europe-wide interest, an editorial decision was made to accommodate a longer report (e.g. Germany, Cyprus and Estonia).

In terms of the timeline, it should be noted that the majority of the reports were submitted during 2015, with some having been received in 2014 and some later in 2016. The Comparative Study was written in 2016-2019. The publication of the national reports was delayed, as the comparative analysis was initially meant to take the form of a shorter comparative report to be included in the present volumes. However, as the analysis grew in length, depth and breadth, it was eventually decided that it would be published as a separate but linked book.

It is important to note that the aim of the project was to take stock of and identify the challenges posed to the Member States' constitutional law up until 2014-2015; the reports and the Comparative Study do not include more recent developments. This book therefore does not cover the Brexit referendum (although a brief post scriptum note has been added to the British report), France's state of emergency regime after the November 2015 terrorist attacks in Paris or the developments in Poland from autumn 2015 that prompted the European Commission to act under the EU rule of law framework. The book also does not explore the recent, more wide-spread turn towards illiberal constitutional trends, at least beyond the national report on Hungary.

Instead, the project explores the deeper comparative European constitutional culture and the approach to the rule of law as it had been consolidated before the financial crisis and before the other more recent crises and illiberal developments. The project examines the common and diverse elements in the comparative European constitutional landscape, and how these have been affected

\footnotetext{
${ }^{26}$ With the exception of the report on Switzerland (see below).
} 
or changed by the ongoing transition to autonomous EU constitutional law and global governance. In the accompanying Comparative Study, the comparative European constitutional achievements prior to the recent illiberal turn are collated and documented in greater detail, in the hope that these will serve as guidance for a quest to restore the values of European constitutionalism that have been eroded, and help shield the values that remain.

\section{The Structure of the Two-Volume Book: The Categorisation and Typology of Europe's National Constitutional Cultures}

The national reports are structured in the present two-volume book on the basis of a somewhat revised typology of Europe's national constitutions, which is developed and explained in greater detail in the linked Comparative Study. As was once remarked by Dieter Grimm, former judge of the German Federal Constitutional Court and one of the national constitutional experts for Germany, '[t]ypologies are not ends in themselves. They help to answer questions' depending on the 'research interests that a scholar of constitutionalism pursues'. ${ }^{27}$ The basis for the typology that underlies the structure of the present book is the dichotomy between historical constitutions on the one hand and revolutionary constitutions on the other, as developed by Leonard Besselink and outlined in the Questionnaire. ${ }^{28}$ A similar division of Europe's national constitutions has also been suggested by other scholars, at times with somewhat different terminology. For example, Cesare Pinelli writes about 'evolutionary' or incrementally evolving constitutions, 'artificial' constitutionalism that prevailed on the European continent since the 1789 Revolution, and the more recent formation of a constitutional tradition in continental Europe that was based on the collapse of totalitarian regimes. ${ }^{29}$ Within the present research project, the categorisation of the constitutional systems became somewhat more nuanced as the national reports were gradually received and as the broad and diverse landscape of national constitutions in Europe began to reveal itself to the editors of the book. As will be explained briefly in this introductory chapter, the categorisation of the constitutional systems is closely linked to the essence of the research question pursued by this project, which is how EU law and global governance have affected the different national constitutional cultures. Whilst in the mainstream EU discourse, national constitutions have typically been approached as a relatively monolith set of instruments that primarily protect

\footnotetext{
${ }^{27}$ Grimm 2012, pp. 98-99.

${ }^{28}$ See Besselink 2006, p. 113 et seq., and as summarised in the Questionnaire [Questionnaire for the Constitutional Law Experts of the Research Project 'The Role and Future of National Constitutions in European and Global Governance'], Sect. 1.1.1 in this book.

${ }^{29}$ Pinelli 2016, p. 258 and, on the same page, footnotes 4 and 5, with references.
} 
sovereignty, the present bottom-up study allows for the perspective to be broadened by looking at the effects of EU law in specific areas of constitutional culture, such as fundamental rights protection, rule of law safeguards and constitutional review.

Following the above revised typology, in the first category, as explained in greater detail in the accompanying Comparative Study, are the political or historical constitutions. These constitutional systems are characterised by the predominance of parliament and the absence of or a weak role for a constitutional court, and by a generic bill of rights that in some cases is historically older or based on the European Convention on Human Rights (ECHR). Additionally, the broader orientation of these constitutions is to incrementally incorporate changes ex post facto rather than to pre-determine the acceptable margins of behaviour for institutions in advance. In this category, we have placed the United Kingdom, Malta, the Netherlands, Luxembourg, and the Nordic countries Sweden, Denmark and Finland. Emblematically, the national report on the Netherlands is entitled 'The Pragmatics of a Flexible, Europeanised Constitution'. It emerges from the report that the Constitution, which dates back to 1814-15, bans constitutional review of Acts of Parliament, and constitutional rights are not justiciable upon the judicial review of Acts, with the ECHR and the EU Charter being applied instead. ${ }^{30}$ The national reports on these constitutional cultures are placed in the opening part of the book (Part II), after the introductory chapters (Part I). The Constitution of Switzerland, which is explored in a separate chapter, also belongs to this type of constitutional culture.

This category is followed by what in Besselink's dichotomy are referred to as 'revolutionary' constitutions, which have a strongly legal character and are enforceable by courts (Parts III-V of the book). In general constitutional theory, this type are also referred to as 'legal' constitutions. The majority of the constitutions of the Member States of the European Union can be considered as 'legal' or 'revolutionary' in character. However, as explained in greater detail in the Comparative Study, in this project the category of 'legal' or 'revolutionary' constitutions is divided into two sub-categories, which would seem more expressive in terms of conveying the constitutional impact of the EU constitutional order on the different constitutional cultures. The new proposed sub-categories are:

(1) post-totalitarian or post-authoritarian constitutions; and

(2) traditional or hybrid legal constitutions, which have strict elements combined with historical or flexible, less prescriptive aspects. ${ }^{31}$

The central features of the constitutions in the first of these sub-categories - the post-totalitarian or post-authoritarian constitutions - stand in clearest contrast to the features that characterise the political or historical constitutions. In the post-totalitarian constitutional cultures, which embody the 'Never again' ethos, constitutional review

\footnotetext{
${ }^{30}$ The report on The Netherlands by Besselink and Claes in this book [The Netherlands: The Pragmatics of a Flexible, Europeanised Constitution].

${ }^{31}$ For an explanation of this categorisation, see a brief explanation below in this section, and a fuller explanation with references to literature in the accompanying Comparative Study.
} 
by constitutional courts plays a central role, the constitutions contain extensive and detailed bills of rights, and the constitutions and constitutional courts pre-determine the margins of constitutionally acceptable political behaviour. The post-totalitarian or post-authoritarian constitutions are presented in two groups, and are referred to hereinafter as the 'post-totalitarian' constitutions; the differences between totalitarian and authoritarian regimes will be explained in greater detail in the Comparative Study. The first group of post-totalitarian constitutions are those adopted after the atrocities of the Second World War in Germany and Italy, and those adopted after the end of the dictatorships of the 1970s in Spain, Portugal and Greece (Part III of the book). The second group are the post-communist constitutions of Central and Eastern Europe, adopted or brought back to life in the 1990s in the aftermath of the fall of the Berlin Wall in 1989. Here we study the constitutions of the countries that became the 'new' Member States: Poland, the Czech Republic, Slovakia, Slovenia, Estonia, Latvia, Lithuania, Romania, Bulgaria and Croatia (Part IV of the book). These countries share a history of arbitrary exercise of power under socialist and communist regimes. Accordingly, their constitutions have entrenched strict constitutional safeguards as a reaction to the human rights violations and abuses of public power experienced by the people living under the pre-1990s regimes. ${ }^{32}$

In fact, the eminent constitutionalist Cesare Pinelli regards the above constitutions as representing a broader continental European constitutional tradition, for the understanding of which the collapse of the totalitarian regimes in these countries is essential. ${ }^{33}$ Prompted by a sense that the understanding of this tradition is fading in the mainstream English language EU constitutional discourse and that its classic elements are often brushed aside as representative of old-fashioned protection of sovereignty or of idiosyncratic national constitutional identity, the accompanying Comparative Study embarks on identifying a list of twelve distinctive features of the post-totalitarian type of constitution. These features include the following. Whereas in the political or historical type of constitutions parliament is supreme as an expression of the people's will in line with the influences of the Enlightenment and the French Revolution, in the countries that experienced totalitarianism, the constitutional design had to go further. Here the constitutional design proceeds from the understanding that democracy is not always capable of ensuring rights and the rule of law, and thus they have been removed from the realm of politics and are ensured by constitutional courts. ${ }^{34}$ Furthermore, some core provisions (typically regarding the democratic, social state governed by the rule of law; core fundamental

\footnotetext{
${ }^{32}$ The historical background and the central tenets of the post-communist constitutionalism are explained in particular in the report on the Czech Republic by Kühn with reference to the respective judgments of the Czech Constitutional Court [The Czech Republic: From a EuroFriendly Approach of the Constitutional Court to Proclaiming a Court of Justice Judgment Ultra Vires], Sects. 1.1.1 and 2.1.3, and in the report on Poland (pre-2016) by Biernat and Kawczyńska [The Role of the Polish Constitution (Pre-2016): Development of a Liberal Democracy in the European and International Context], Sects. 1.1.1-1.1.2, in this book.

${ }^{33}$ Pinelli 2016, p. 258.

${ }^{34}$ See e.g. Pinelli 2016, pp. 264-266, and Somek 2014, pp. 15 et seq., 84-85 and 90-95.
} 
rights) are unamendable or subject to a special, stringent amendment procedure, often involving a referendum. With the exception of Greece, the constitutional systems of all post-totalitarian countries feature a strong, centralised constitutional court, ${ }^{35}$ and constitutional review is typically rigorous, with a statistically high rate of annulment of legislation, in particular in cases of so-called abstract review. These courts often follow the intellectual leadership of the German Constitutional Court, and have cemented the legal character of the constitutional safeguards provided in the bills of rights and the clauses protecting the Rechtsstaat or stato di diritto, i.e. 'the state governed by the rule of law'. Crucially, these constitutions embody a value order centred on fundamental rights and based on human dignity; they typically start with extensive, detailed, directly applicable and justiciable chapters on fundamental rights and rule of law safeguards. Indeed, the editors were surprised to find that the respective constitutional provisions - especially as regards safeguards for deprivation of liberty, access to courts and the protection of the home, privacy and secrecy of communications - are often worded in a way that is notably more stringent and/or offers more extensive protection than the relatively generic provisions set out in the ECHR and the EU Charter of Fundamental Rights. The respective provisions are written out in the national reports for ease of reference. These constitutions typically also include extensive provisions on social rights and/or the social state, which form part of the concept of human dignity. This reflects the recognition that a life lived in dignity and with freedom of choice requires that a basic level of material needs is met; based on historical lessons, the social state dimension aims to avoid the root causes of the emergence of authoritarian regimes, which are economic insecurity and dependence. $^{36}$ The overall aim of the constitutional design was to avoid 'a social situation that would [give] rise to mass support for another militant, anti-democratic, populist movement'. ${ }^{37}$ The Comparative Study additionally documents the extensive and often constitutionally codified protection of the rule of law and its different sub-principles (e.g. parliamentary reservation of law; rules on publication of laws; the rules governing the limitation of rights; the principles of legal certainty; legitimate expectations and non-retroactivity) in this constitutional tradition.

The second sub-category of 'legal' or 'revolutionary' constitutions was - after considerable reflection - designated as 'traditional or hybrid legal constitutions', and these are placed in a separate part of the book (Part V). The reference to 'legal' constitutions aims to signify that these constitutions have a legal character, are binding in nature and enforceable in courts, and set the broad, constitutionally acceptable margins for the political institutions and civil servants in advance. However, they also contain more historical, political, or otherwise flexible or less prescriptive elements. The constitutional systems placed in this category are those of France, Belgium, Ireland, Austria and Cyprus. The constitutions of the first four of these countries have historical bills of rights with limited justiciability (e.g.

\footnotetext{
${ }^{35}$ In Estonia, this function is carried out by the Constitutional Review Chamber of the Supreme Court.

${ }^{36}$ For historical background, see e.g. Somek 2014, pp. 10-13, 85-86 and 155.

${ }^{37}$ Somek 2014, pp. 85-86.
} 
France's 1789 Declaration of the Rights of Man and of the Citizen, and Austria's 1867 Basic Law on the General Rights of Nationals), and the protection of fundamental rights is predominantly reliant on the ECHR. In France and Belgium, the mandate for constitutional review was initially confined to guaranteeing respect for the constitutional separation of powers scheme, ${ }^{38}$ and thus full human rights based review is more recent. ${ }^{39}$ In France and Ireland, the approach to judicial review is regarded as deferent to the governing institutions, as observed in the respective national reports. The constitutions date back to the pre-World War II period in Belgium (1831), Austria (1920) and Ireland (1937). The Cypriot Constitution is described in the Cyprus report as 'a hybrid model' due to special circumstances in the country. ${ }^{40}$ The ways in which these constitutional systems are less strict and extensive in protection than the post-totalitarian constitutions are outlined in greater detail in the Comparative Study.

Hungary has been placed in a separate part of the book (Part VI), and an editorial note has been added to the report. In the recent past, Hungary's Constitution was in the category of post-totalitarian constitutions, and its Constitutional Court was widely acclaimed for its activist approach to constitutional review and the protection of fundamental rights and rule of law safeguards. The changes that have occurred since 2010 and which have been widely described as a turn to illiberal constitutionalism are explored in the national report, entitled 'Constitutional (R) evolution or Regression?'. 41

The national report on Poland, a country which has recently followed the trend of illiberal constitutional reforms started by Hungary, was completed before these developments began to unfold. For the purposes of this study, therefore, the Polish Constitution is considered to be in the category of post-totalitarian constitutions in the 'new' Member States. It is notable that based on the case law of the Polish Constitutional Tribunal cited in the Polish report, ${ }^{42}$ it is evident that at least up until

\footnotetext{
${ }^{38}$ De Visser 2014, p. 7

${ }^{39}$ In France, fundamental rights did not become justiciable for individuals until 2010, following a constitutional amendment of 2008 whereby ex post control of constitutionality was introduced into French constitutional law, allowing individuals to challenge the constitutionality of legislative provisions that violate their rights. The Belgian Constitutional Court was established relatively lately, in the 1980s - first as the 'Court of Arbitration' - with the task of adjudicating federal competences. Fundamental rights review of legislation was formally introduced in 2003. See, respectively, the report on France by Burgorgue-Larsen, Astresses and Bruck [The Constitution of France in the Context of EU and Transnational Law: An Ongoing Adjustment and Dialogue to Be Improved], and the report on Belgium by Popelier and Van de Heyning [The Belgian Constitution: The Efficacy Approach to European and Global Governance], in this book.

${ }^{40}$ See the report on Cyprus by Kombos and Laulhé Shaelou in this book [The Cypriot Constitution Under the Impact of EU Law: An Asymmetrical Formation].

${ }^{41}$ The report on Hungary by Chronowski, Varju, Bárd and Sulyok in this book [Hungary: Constitutional (R)evolution or Regression?].

${ }^{42}$ See the report on Poland by Biernat and Kawczyńska in this book [The Role of the Polish Constitution (Pre-2016): Development of a Liberal Democracy in the European and International Context].
} 
that time (autumn 2015), the Polish Constitutional Tribunal had taken one of the most stringent approaches to the protection of the post-totalitarian understanding of constitutionalism and the rule of law, including in the context of EU law. This deserves wider awareness, as in the mainstream European constitutional discourse, many of the respective cases of the Polish Constitutional Tribunal (pre-2016) have in a somewhat reductionist and even unfair manner been portrayed as representative of a Eurosceptic and sovereignty-protective approach.

The final part of the book (Part VII) contains the report from Switzerland, which is the only country covered by this research project that is not a member of the EU. Experts from Switzerland were invited to participate because of the important constitutional reforms adopted in Switzerland to guarantee parliamentary participation in global governance issues as well as a role for direct democracy in these matters. ${ }^{43}$ It emerges from the other reports that the Swiss reforms, by and large and comparably speaking, can be considered both pioneering as well as extensive. In other countries, international law has traditionally remained a matter of one-way reception. It is thus hoped that the Swiss experience will be of considerable wider interest, and will foster thinking and discussion elsewhere.

\section{The Comparative Study: Outlining the Broader Trends and Processes Emerging from the National Reports}

The wealth of material collated in the national reports is synthesised in a comparative monograph written by the Principal Investigator of the project, Anneli Albi. This will be published as an accompanying, linked book entitled National Constitutions in European and Global Governance: Democracy, Rights, the Rule of Law. A Comparative Study (T.M.C. Asser Press, 2019), and is referred to in the present book as the 'Comparative Study'. ${ }^{4}$ The Comparative Study outlines a number of important issues and challenges that are shared by a significant (but not always overlapping) range of Member States. Furthermore, it identifies broader, overarching trends and processes that at times surprised the editors and in our view warrant wider attention.

By way of examples, these include the shift in a large number of Member States from the rule of parliamentary reservation of law to the use of governmental decrees when implementing EU law, including - somewhat strikingly when limiting fundamental rights and imposing sanctions.

\footnotetext{
${ }^{43}$ See the report on Switzerland by Kunz and Peters in this book [Constitutionalisation and Democratisation of Foreign Affairs: The Case of Switzerland].

${ }^{44}$ Readers writing a book review are kindly asked to obtain a copy of both books - the two-volume book with the national reports as well as the Comparative Study - from the publisher, and to review these together.
} 
The existence of a wider, endemic strain on constitutional values emerged most clearly in relation to the near-automatic process of extraditions under the European Arrest Warrant system. Numerous ombudspersons, NGOs and associations of defence lawyers, courts and especially lower instance courts, a considerable number of dissenting judges in the highest national courts, as well as other institutions and scholars - especially scholars in the field of criminal law - in a large number of Member States have expressed significant concerns about the presumption of innocence and other defence rights, and about the absence of judicial review in extradition cases. Judicial review is not allowed even in cases where serious fundamental rights concerns have been expressed in the context of deprivation of personal liberty. Strikingly, in several reports it was observed that the European Commission, in its critical evaluation reports, has required constitutional and legislative amendments to remove protective provisions in the Member States (see especially the accounts in the reports on Cyprus, Croatia, Ireland and Italy).

Regarding the EU Data Retention Directive, whilst in the mainstream European discourse the constitutional challenges have widely been portrayed as cases representing national constitutional identity, it emerged that privacy and protection of home and correspondence have 'deep roots' in the continental European constitutional tradition. ${ }^{45}$ They have especially been subjected to heightened protection and safeguards in the post-totalitarian constitutions, given the historical experience of these countries with pervasive state surveillance. Although the Directive was eventually annulled by the CJEU on the second round, the far-reaching consequences have been difficult to undo. A 'taboo' was broken, as observed above in the Austrian report. As with the EAW, there has been a spillover from the originally intended use for serious crime into other areas. Additionally, in a development representative of a wider trend, a uniform, autonomous, self-referential standard was set by the CJEU in Digital Rights Ireland ${ }^{46}$ on the basis of Arts. 7 (privacy) and 8 (data protection) of the EU Charter combined with the principle of proportionality. The more stringent approach and the diversity of the rights protected under many national constitutions and by many national constitutional courts were by and large displaced.

By way of examples from other areas, in the approach to the rules on publication of laws, for post-totalitarian constitutional systems there has been a shift through CJEU case law from the rule that an unpublished law is void and non-existent $a b$ initio/ex tunc to the 'valid but not enforceable against individuals' approach that applies in France and Belgium. Similarly, with regard to the post-totalitarian constitutional systems, the Comparative Study documents significant changes in the approach to limitation of fundamental rights and in the interpretation of the principles of legitimate expectations and non-retroactivity as

\footnotetext{
${ }^{45}$ Hogan 2014, pp. 162-164. See also the report on Ireland by Hogan in this book [Ireland: The Constitution of Ireland and EU Law: The Complex Constitutional Debates of a Small Country], Sect. 2.10.1.

46 Joined cases C-293/12 and C-594/12 Digital Rights Ireland and Seitlinger and Others [2014] ECLI:EU:C:2014:238.
} 
well as the principle of proportionality through CJEU case law. Additionally, several national reports mentioned strains on legal certainty and on the clarity and 'quality of law'. 47 A further host of profound changes emerged in a chapter exploring the 'relocation' of judicial review from constitutional courts to the European Court of Justice in increasingly wide areas of law. These changes are discussed in the Comparative Study in the light of emerging literature where concerns have been expressed about the displacement or exclusion of constitutional courts and national highest courts, along with their well-established case law. ${ }^{48}$

Another area where widespread disquiet emerged concerns the severe and prolonged erosion of the social state dimension of Europe's post-totalitarian and some traditional legal constitutions through the EU and/or IMF euro crisis measures, e.g. by curtailing social rights (as well as funding for social benefits by redirecting state funds e.g. to the ESM) and reducing the protection of workers. ${ }^{49}$ The strain on the social state is most clearly evident in the reports on Portugal, Greece, Latvia, Romania and Spain. ${ }^{50}$ The euro crisis developments are further explored from the perspective of constitutionalisation as constitutional entrenchment - through the Treaties - of a certain economic order. As part of this broader theme, the Comparative Study explores constitutional issues relating to the

\footnotetext{
${ }^{47}$ This issue is explored report on Finland by Ojanen and Salminen [Finland: European Integration and International Human Rights Treaties as Sources of Domestic Constitutional Change and Dynamism], the report on Cyprus by Kombos and Laulhé Shaelou [The Cypriot Constitution Under the Impact of EU Law: An Asymmetrical Formation] and the report on Denmark by Krunke and Baumbach [The Role of the Danish Constitution in European and Transnational Governance] in this book. For specific guidance that implementation of EU law ought not to weaken the 'quality of law', see the work of the Finnish Parliament's Constitutional Law Committee, as outlined in the report on Finland by Ojanen and Salminen in this book [Finland: European Integration and International Human Rights Treaties as Sources of Domestic Constitutional Change and Dynamism], Sect. 2.3.6.

${ }^{48}$ See e.g. Komárek 2014, pp. 16 et seq.

${ }^{49}$ Whilst the observations regarding the social welfare dimension are also relevant e.g. with regard to the Nordic countries, in the political type of constitutions, social rights tend to be regulated at the legislative level rather than being entrenched through the text of the constitution. As it was seen above (see the text accompanying links to n. 36 and 37 respectively), historically, in the case of Germany and subsequently other post-totalitarian constitutions, protection of the social state was prompted by the lessons that the root causes of the rise of authoritarian and totalitarian governments are economic insecurity and dependence. This historical observation would seem to have significant contemporary relevance, but has perhaps been unduly neglected in the prevailing discourse where recent illiberal developments have predominantly been attributed somewhat generically to populism and nationalism.

${ }^{50}$ See the report on Portugal by Pereira Coutinho and Piçarra [Portugal: The Impact of European Integration and the Economic Crisis on the Identity of the Constitution], the report on Greece by Contiades, Papacharalambous and Papastylianos [The Constitution of Greece: EU Membership Perspectives], the report on Latvia by Krūma and Statkus [The Constitution of Latvia - A Bridge Between Traditions and Modernity], the report on Romania by Iancu [Romania - The Vagaries of International Grafts on Unsettled Constitutions], and the report on Spain by Solanes Mullor and Torres Pérez [The Constitution of Spain: The Challenges for the Constitutional Order Under European and Global Governance] in this book.
} 
privatisation of public services and the entrenchment of independent regulatory agencies in the process of market liberalisation, which are mentioned in several national reports. ${ }^{51}$

The revised typology of constitutional systems that was briefly outlined in the preceding section is relevant for the understanding of the broader patterns that emerge in the Comparative Study in terms of whether $\mathrm{EU}$ law has given rise to constitutional conflicts in individual Member States. It should be noted that the study here does not concern areas where rights have been advanced - typically in an activist manner - in fields of EU law such as free movement, non-discrimination, gender equality and consumer protection, which have been extensively researched in the existing literature. ${ }^{52}$ In general terms - with of course exceptions - a pattern can be discerned whereby EU law has strengthened the protection of fundamental rights and the general principles of law and has expanded judicial review in countries with a political or historical constitutional system. However, this strengthening has often come at the cost of a reduction in the priority of parliamentary and democratic processes. These developments are perhaps most evocatively captured in the titles of the national reports from the UK ('Europe's Gift to the United Kingdom's Unwritten Constitution - Juridification, ${ }^{53}$ ) and Sweden ('The Constitution of Sweden and European Influences: The Changing Balance between Democratic and Judicial Power ${ }^{54}$ ). At the same time, EU law has caused strain with regard to the standards previously established by the constitutional courts in the Member States with a post-totalitarian constitutional culture, both in

\footnotetext{
${ }^{51}$ See the report on Spain by Solanes Mullor and Torres Pérez [The Constitution of Spain: The Challenges for the Constitutional Order Under European and Global Governance], the report on Portugal by Pereira Coutinho and Piçarra [Portugal: The Impact of European Integration and the Economic Crisis on the Identity of the Constitution], the report on Belgium by Popelier and Van de Heyning [The Belgian Constitution: The Efficacy Approach to European and Global Governance], the report on Slovenia by Bardutzky [The Future Mandate of the Constitution of Slovenia: A Potent Tradition Under Strain], the report on Austria by Lachmayer [The Constitution of Austria in International Constitutional Networks: Pluralism, Dialogues and Diversity], the report on Croatia by Goldner Lang, Đurđević and Mataija [The Constitution of Croatia in the Perspective of European and Global Governance], the report on Finland by Ojanen and Salminen [Finland: European Integration and International Human Rights Treaties as Sources of Domestic Constitutional Change and Dynamism], and the report on Hungary by Chronowski, Varju, Bárd and Sulyok [Hungary: Constitutional (R)evolution or Regression?] in this book.

52 This so-called 'double standards' issue is explained in greater detail in the Questionnaire in this book [Questionnaire for the Constitutional Law Experts of the Research Project 'The Role and Future of National Constitutions in European and Global Governance'] (Introduction to Sect. 2 and Sect. 2.6.1). See also Coppel and O'Neill 1992, pp. 670 et seq.

${ }^{53}$ See the report on the United Kingdom by Young, Birkinshaw, Mitsilegas and Christou in this book [Europe's Gift to the United Kingdom's Unwritten Constitution - Juridification].

${ }^{54}$ The report on Sweden by Nergelius in this book [The Constitution of Sweden and European Influences: The Changing Balance Between Democratic and Judicial Power].
} 
Western Europe and in Central-Eastern Europe. ${ }^{55}$ This is conveyed in the clearest terms in the title of the Slovenian report ('The Future Mandate of the Constitution of Slovenia: A Potent Tradition Under Strain ${ }^{56}$ ). This finding has a further important dimension in the light of other observations in the national reports which we initially noted with interest and subsequently with an increasing sense of unease - concerning the numerous direct and indirect ways in which EU law and the CJEU case law have led to the uniformisation and homogenisation of the Member States' constitutional law. This includes the transition to a uniform ECHR/EU Charter standard in increasingly wider areas of law, including where this entails downgrading national standards of protection.

Another broader pattern in terms of correlation between the type of constitution and the effects of EU law emerged in relation to constitutional amendments regarding European integration. In broad lines, this could be based on a distinction between an 'efficacy approach' and a 'legitimacy approach', which is drawn in the Belgian report on the basis of Patricia Popelier's study of EU clauses in the national constitutions. ${ }^{57}$ As summarised in the Belgian report:

Two main approaches can be discerned: an 'efficacy approach', which is predominantly occupied by the concern for efficient through-put of EU law, and a 'legitimacy approach', which is specifically concerned with providing legitimacy to inflowing EU law. If a legitimacy approach is adopted, ideally, (a) the transfer of powers is submitted to special procedural and/or substantive conditions, (b) the precedence of EU law over the constitution is contested and (c) constitutional or supreme courts play the role of watchdogs over the constitution, assuming the power to ultimately delineate competences. If an efficacy approach is adopted, (a) the transfer of powers to the EU is allowed without special formal conditions, (b) the precedence of EU law over national law, including the constitution, is uncontested and (c) the judicial review of EU laws and treaties is constrained. ${ }^{58}$

Popelier's study observes that in Belgium, the Netherlands and Luxembourg, an efficacy approach clearly dominates, with Germany being on the other side of the spectrum. ${ }^{59}$ This research finding is confirmed in the Comparative Study. ${ }^{60}$

\footnotetext{
${ }^{55}$ It is important to note that these conclusions specifically concern the rights explored in the project Questionnaire. In other areas, e.g. as regards prison conditions, media pluralism, the strength of civil society and the actual level of social welfare entitlements, the countries with a political or historical constitutional culture often have some of the highest standards in Europe.

56 The report on Slovenia by Bardutzky in this book [The Future Mandate of the Constitution of Slovenia: A Potent Tradition Under Strain].

${ }^{57}$ Popelier 2014, as summarised in the report on Belgium by Popelier and Van de Heyning in this book [The Belgian Constitution: The Efficacy Approach to European and Global Governance], Sect. 1.5.3.

${ }^{58}$ The report on Belgium by Popelier and Van de Heyning in this book [The Belgian Constitution: The Efficacy Approach to European and Global Governance], Sect. 1.5.3.

${ }^{59}$ Popelier 2014, p. 316.

${ }^{60}$ See also, for example, the extensive constitutional conditions and adjudication outlined in the report on Germany by Grimm, Wendel and Reinbacher [European Constitutionalism and the German Basic Law], and the observations about the absence of constitutional conflicts in the report
} 
Additionally, it emerges that a solution akin to the 'efficacy' approach has also been adopted in Ireland, Cyprus and Estonia, whereas the 'legitimacy' approach prevails in most of the post-totalitarian constitutional cultures. The tensions that an 'efficacy'-based approach presents to a post-totalitarian constitution that has been influenced by the German Constitution are perhaps most evident in the Estonian report. What might appear to be the ideal solution from the perspective of the EU legal order - suspending conflicting constitutional provisions in order to ensure the full supremacy and effectiveness of EU law - has led to widespread concerns amongst Estonian lawyers about negating the hitherto binding, enforceable and rights-protective Constitution, as well as to practical difficulties in constitutional adjudication by the Supreme Court. ${ }^{61}$

Whilst the working title of the book was 'The Role of National Constitutions in European and Global Governance', the above findings led us to expand the title and add 'Democracy, Fundamental Rights, the Rule of Law'. With this subtitle, we sought to draw attention to the fact that these values have in fact been central to the national constitutions since the Enlightenment, and that these values have also provided the key, expressly worded conditions governing the transfer of powers to the supranational level, especially in the constitutions of Germany, Slovenia and Portugal, as well as in the case law of many constitutional courts. This is important to bear in mind, given that in the mainstream European constitutional discourse, the national constitutions have primarily come to be associated with a somewhat old-fashioned protection of sovereignty or, more recently, national constitutional identity. Sovereignty and the assessment of Euro-friendliness or Euroscepticism have also been the prevailing lens of assessment in the scholarly literature on constitutional courts, where unduly harsh and reductionist language has often been used with regard to those constitutional courts that have sought to retain some degree of constitutional review or uphold constitutional values in the context of EU law. ${ }^{62}$ In the Comparative Study, it is submitted that many of the constitutional rights and values that have come under strain in the context of EU law are in fact comparative European constitutional achievements, ${ }^{63}$ which in several aspects quite possibly represent the most advanced constitutionally codified and judicially protected fundamental rights, social rights and rule of law safeguards in

on Luxembourg by Gerkrath [The Constitution of Luxembourg in the Context of EU and International Law as 'Higher Law'], both in this book.

${ }^{61}$ For a summary of the discourse, see the report on Estonia by Ernits, Ginter, Laos et al. in this book [The Constitution of Estonia: The Unexpected Challenges of Unlimited Primacy of EU Law] in this book, Sects. 1.2.3, 1.2.4, 1.5.3, 1.3.4, 2.3, 2.7 and 2.8.

${ }^{62}$ These trends in the scholarly literature have been documented with references in Albi 2015a, Sect. I and Albi 2015b, Sect. VIII.

${ }^{63}$ The expression 'constitutional achievements' is borrowed from Dieter Grimm, who uses it more generally in relation to the democracy and rule of law elements in modern constitutions (Grimm 2012, p. 104). See also Somek (2014, p. 10), who regards especially the constitutions based on the German model as representing the emancipation of constitutionalism - see below n. 99 and the accompanying text. 
the world. However, the understanding of these has started to fade, as will be noted below.

At this juncture, it should be underlined that throughout the project, EU and international treaties and rules that protect human rights, ensure peace or enhance environmental protection are regarded as part of the constitutional achievements. Indeed, especially the ECHR has a constitutional or semi-constitutional status in the internal legal order of a large number of the countries studied. However, the material synthesised would seem to indicate a need for a more differentiated and nuanced approach in discussions on the domestic constitutional reception, on the one hand, of the above type of treaties and, on the other hand, of treaties and instruments that may have adverse effects on rights and constitutional values or that significantly curtail democracy beyond the constitutionally entrenched values. Some examples of such adverse effects from EU law were brought earlier in this section (e.g. the European Arrest Warrant and the Data Retention Directive). Regarding some constitutionally problematic examples from international and global law, the reader is invited to take a look at the following accounts in the national reports: the cases regarding IMF and/or European Commission instruments whereby already subsistence-level pensions and social benefits were drastically cut and social rights were curtailed along with the principle of legitimate expectations (reports on Latvia, Portugal, Greece and Romania; see also more generally the report on Spain); the adjudication of international extradition treaties (reports on Poland, the UK, Cyprus, Portugal, France); issues around access to judicial review regarding measures implementing targeted sanctions against individuals under the UN anti-terrorist resolutions and blacklists (reports on Belgium, Switzerland and the UK); the question whether parliamentary ratification and/or implementation by parliamentary law is needed for international instruments such as extradition treaties, UN sanctions targeting individuals, and IMF memorandums of understanding and loan agreements (reports on Latvia, Finland, Ireland and Belgium); the role of private actors in global governance, including their unpublished but binding technical standards (reports on the Netherlands, Estonia and Austria); transparency and access to documents in the context of international co-operation (the reports on Sweden and Finland); and constitutional issues regarding the effects of international investment arbitration treaties (reports on Romania and the UK).

Regarding the material in the national reports, in addition to outlining the domestic case law and legal discussion, we also invited the constitutional law experts to express their own views on how some of the older and more recent points of debate in the EU constitutional and judicial dialogues could be addressed. For example, we asked for the experts' assessments relating to the provision of higher standards of protection, if hitherto so provided under the national constitution, in the context of the ongoing debate regarding Art. 53 of the EU Charter. What role do the experts see for the common constitutional traditions? Would there be value in bringing national constitutional concerns to the CJEU and other European institutions and, if so, what avenues ought to be used? And, ultimately, how do the constitutional scholars see the role of national constitutions in 
European and global governance? The editors are immensely grateful to the project experts for joining us in constructively thinking about the new challenges to constitutional law posed by transnational governance. Their key observations are summarised in the Comparative Study, along with some specific policy recommendations.

The Comparative Study concludes with broader observations about an ongoing, gradual process of transition from the paradigm of (comparative) constitutional and public law to the paradigm of governance that prevails in EU law and large parts of transnational law. ${ }^{64}$ The governance paradigm is predicated on a different underlying logic, which in the main seems to have emanated from the neofunctionalist thinking that underlies much of the European integration and transnationalisation processes and discourses. Other underlying theoretical constructs of the governance paradigm include e.g. the '[c]ontemporary delegation theory, with its emphasis on principal, agents, and dilemmas of agency control', which 'is an adaptation of concepts of contract law to the political world', including concepts from fiduciary constitutionalism, the law of trusts and other private law concepts. ${ }^{65}$ It is not easy to reconcile these theories and classic constitutionalism. For example, the core tenets of neofunctionalism that drive supranational governance are integration-through-law, spillover, 'never let a good crisis go to waste', and the mobilisation of and instrumental use of law, of courts, institutions, political, bureaucratic and business elites, scholarship, as well as individuals and their rights towards a gradual shift of law, authority and loyalty from the national to the supranational level. ${ }^{66}$ Whilst this has led to many progressive developments with lasting, beneficial changes, there is a structural flaw in neofunctionalist constitutionalism, in that it views national constitutional law as inherently inferior for the simple reason that it is national and based on a sovereign state. There has been a blind spot to and fading understanding of the comparative European constitutional achievements, which in many respects may quite possibly be the most advanced in

\footnotetext{
${ }^{64}$ Some aspects of such a paradigm change from constitutional and public law to governance have been identified by the following scholars: Joana Mendes (with regard to transnational technical regulatory regimes with norms that acquire the status of EU legal acts and also acquire supremacy through incorporation into EU law without traditional avenues for participation (Mendes 2014, p. 371)); Alexander Somek (in EU governance, constraints on public power have become economic (Somek 2014, pp. 23-24; see also above n. 13 and the accompanying text)) and Agustín Menéndez (conceptual innovation in legal research (Menéndez 2014, p. 140; see below n. 85 and the accompanying text)).

${ }^{65}$ Cf. e.g. Sweet and Brunell 2013, p. 67, with further references, including the influential writings of Giandomenico Majone.

${ }^{66}$ For an overview of the core tenets of neofunctionalism, see e.g. De Búrca 2005, pp. 316 et seq. and Sweet 2012. The Principal Investigator would like to acknowledge that the draft chapters of Maris Moks' Ph.D thesis 'Guardianship of the Constitution versus the Expectations of the European Integration: Judicial Review of the Euro-crisis Management' (Hertie School of Governance in Berlin), which contained an extensive literature review, greatly helped her to formulate the broader observation about a change from the constitutional law mindset to a neofunctionalist mindset, especially as regards the changing role of courts towards agents of integration in the neofunctionalist theory.
} 
the world, as noted above. A good example to illustrate the difference between the neofunctionalist and the comparative European constitutional thinking is the commentary on the Pupino case. ${ }^{67}$ Lawyers specialising in EU law widely regard it as a milestone 'constitutional' case, as it extended indirect effect, effectiveness and loyal co-operation to the then third pillar. Lawyers specialising in the field of constitutional law and criminal law, however, point out that the case concerned application in the field of criminal trials of a framework decision that had not yet been implemented in national law and that had furthermore been adopted at the ministerial level by the EU Council. These aspects raise profound concerns from the point of view of the classic values protected in Europe's national constitutions, such as the principles of the rule of law, including maximum certainty in criminal law, clearly determined provisions and democratic legitimisation by parliamentary law. $^{68}$

A tentative list of foundational changes in the transition from the classic constitutional law paradigm to the governance paradigm is compiled in the Comparative Study. Examples of such foundational changes include: a broader shift from constitutions to the Treaties as the normative point of reference and thereby to a market-oriented order or - in the euro crisis governance - to the exercise of public power simply on the basis of general economic exigencies; a shift from constitutional and rule of law requirements to the prioritisation of effectiveness, policy objectives and functionality; a changing understanding of the role of courts and constitutional courts in the neofunctionalist literature and in practice; a change away from the liberal separation of powers to a new autonomous system; an approach to fundamental rights whereby fundamental rights are treated as restrictions to economic freedoms and are ultimately subordinated to them as well as to the imperatives of uniformity and effectiveness; a changing understanding of the rule of law; the disappearance of constitutional law as higher law; and the manifold changes at the EU and national level towards executive governance, especially the gradual phasing out of national level democracy and the chain of legitimacy between public power and a territorial community of people. The severe curtailment of parliamentary democracy and control over the budget due to the very large financial liabilities undertaken by virtue of the ESM Treaty have been subject to particularly acute constitutional debates and challenges in Germany, Estonia, Ireland, Austria, Poland and to some extent in Lithuania, as documented in the respective national reports. In addition, the issue of parliamentary control over large-scale state guarantees was also at stake in the EFSF (European Financial Stability Facility) case before the Slovenian Constitutional Court.

\footnotetext{
${ }^{67}$ Case C-105/03 Pupino [2005] ECR I-05285.

${ }^{68}$ For a critical assessment of the constitutional significance of Pupino for EU law, see Herlin-Karnell 2007, pp. 1151 and 1154. More generally on the uneasy fit between EU criminal law and classic values in European criminal law and constitutional law, see the concerns of fourteen scholars in the 'Manifesto on the European Criminal Policy' (2009) Zeitschrift für Internationale Strafrechtsdogmatik, Issue 12, 70-716, at 715, available online at http://www. crimpol.eu/; Schünemann 2007, p. 227; Walsh 2009, pp. 5-34.
} 
A more general foundational change may be, as a number of leading political scientists have observed, that the governance model is 'post-political' or 'unpolitical', and in fact oriented towards constraining dissent. ${ }^{69}$ The picture that emerges from the national reports does little to alleviate this concern. For one, there is a near-absence of formal structures for invoking national constitutional grounds at the EU level, at least beyond the subsidiarity and proportionality arguments for national parliaments and for the national constitutional identity ground in judicial proceedings. Indeed, the Maltese expert makes the very commendable suggestion to extend the ex ante yellow card mechanism of national parliaments to a fuller monitoring procedure, which would include essential constitutional concerns beyond subsidiarity and proportionality. ${ }^{70}$ The severely constrained scope for national level democratic protest or even for constitutional review by constitutional courts is perhaps most compellingly evident in the proceedings in which the European Commission threatened or imposed fines on Sweden and Germany for delays in implementing the Data Retention Directive, explored in the respective national reports. The scope for demonstrations and protest has been further reduced in different ways by CJEU rulings in cases such as Schmidberger, Viking Line and Laval, ${ }^{71}$ as well as by the European Commission and IMF economic conditionality measures that require the curtailing of trade union rights. ${ }^{72}$ In general, we observed a near-absence of debate in a considerable number of countries ${ }^{73}$ regarding EU measures that in many other Member States had raised heightened concerns and extensive discussion about deficiencies in rights protection.

The Comparative Study further explores the corresponding changes in constitutional thinking and constitutional vocabulary, which have increasingly become the default, new baseline for constitutionalism, especially for the younger generations of scholars and lawyers. Indeed, one point of added value of the national reports is that many of them contain detailed documentation of the clashes between the classic constitutional thinking and the governance-oriented mindset.

\footnotetext{
${ }^{69}$ For references to literature, see Bouza Garcia 2017, pp. 348, 349, 340.

${ }^{70}$ The report on Malta by Xuereb in this book [The Constitution of Malta: Reflections on New Mechanisms for Synchrony of Values in Different Levels of Governance], Sects. 2.12.3 and 2.13.4.

${ }^{71}$ Case C-112/00 Schmidberger [2003] ECR I-05659; Case C-438/05 The International Transport Workers' Federation and The Finnish Seamen's Union [2007] ECR I-10779; Case C-341/05 Laval un Partneri [2007] ECR I-11767.

72 On the latter, see especially report on Spain by Solanes Mullor and Torres Pérez [The Constitution of Spain: The Challenges for the Constitutional Order Under European and Global Governance], and the report on Greece by Contiades, Papacharalambous and Papastylianos [The Constitution of Greece: EU Membership Perspectives], in this book.

${ }^{73}$ The absence of debate is in particular mentioned in the report on Lithuania by Jarukaitis and Švedas [The Constitutional Experience of Lithuania in the Context of European and Global Governance Challenges], the report on Slovakia by Vikarská and Bobek [Slovakia: Between EuroOptimism and Euro-Concerns], and the report on Bulgaria by Tanchev and Belov [The Bulgarian Constitutional Order, Supranational Constitutionalism and European Governance] in this book.
} 
A careful reader may well observe that the former tends to remain on the dissenting or losing side (e.g. the grounds and arguments used by dissenting judges, traditional constitutional litigants such as ombudspersons, defence lawyers' associations and minority groups of MPs). Different aspects of the changes in the constitutional language in the transnational context are more specifically explored in the reports on Italy, Romania and Germany. ${ }^{74}$ On a more general level, the fact that the language of constitutionalism in transnational law has little in common with the world of comparative constitutional law has perceptively been explained on the basis of an extensive literature review by Peer Zumbansen. ${ }^{75}$ Transnational constitutionalisation depicts the dynamic forces of constantly newly emerging functional and specialised fora of law-making. ${ }^{76}$ The risk, according to Zumbansen, is that the focus on limiting or placing constraints on governmental power, which is the central tenet of 'traditional constitutionalism', has been displaced. ${ }^{77}$ The focus is on the autonomy of the emerging global legal order from claims from the nation state, and there has been 'erosion of institutionalized, accountable exercises' of political power. ${ }^{78}$

Whilst scholarly research has hitherto predominantly focused on the benefits of EU and transnational constitutionalism, the present study looks at the risks arising from the way these ongoing processes have changed the application of the classic European understanding of constitutionalism and of the concept of the rule of law. It seeks to invite discussion on the shift to the governance paradigm, along with the merits and demerits of the gradual transition to autonomous EU constitutional law, and on the optimal balance between striving toward uniformisation and retaining the diversity of the national constitutional cultures. Discussion on the profound changes would also seem particularly timely, as the EU is moving towards the mutualisation of debt and ultimately to the EU raising its own revenue that would in the last resort be backed by the Member States, ${ }^{79}$ and whereby individual Member

\footnotetext{
${ }^{74}$ See the report on Italy by Martinico, Guastaferro and Pollicino [The Constitution of Italy: Axiological Continuity Between the Domestic and International Levels of Governance?], the report on Romania by Iancu [Romania - The Vagaries of International Grafts on Unsettled Constitutions], and the report on Germany by Grimm, Wendel and Reinbacher [European Constitutionalism and the German Basic Law], in this book. See also notes 5 and 92 and the accompanying text. The report on Romania [Romania - The Vagaries of International Grafts on Unsettled Constitutions], additionally, makes perceptive observations about the change of the constitutional language in the quasi-constitutionalisation of the EU anti-corruption conditionality in Romania.

${ }^{75}$ Zumbansen 2012, p. 47, see also pp. 31 and 38.

${ }^{76}$ Ibid., p. 47, with further references.

${ }^{77}$ Zumbansen 2012, p. 38, with further references.

${ }^{78}$ Ibid., p. 47.

79 The European Commission sees 'a step-by-step, policy-by-policy basis' advancement towards the latter as the ultimate goal according to its Communication 'A blueprint for a deep and genuine monetary union. Launching a European Debate’ (COM 2012777 final/2 30.11.2012, http://ec. europa.eu/archives/commission_2010-2014/president/news/archives/2012/11/pdf/blueprint_en. pdf). According to the Commission Blueprint, if the guarantee is claimed by creditors, accountability through national parliaments is no longer relevant and shifts to the European Parliament.
} 
States and their parliaments would no longer be in control of their financial liabilities. This may well mark a significant transformative turning point - and one of no return - for classic European constitutionalism.

\section{The Broader Importance of the Project for the Future Direction of Travel for National, Comparative European, EU and Global Constitutionalism}

We hope that the readers will come to agree that such thinking and discussion about the future direction of travel for European constitutionalism is of real and pressing importance. In the past, EU law has been developed primarily in a top-down, autonomous, self-referential manner from the perspective of the needs and priorities of the EU legal order. On the one hand, European integration has brought important, lasting benefits, which include peace and stability, relative prosperity, freedom of movement and the broadening of important opportunities for individuals for greater self-realisation and enriched horizons. Indeed, all of the national reports in the present book strongly emphasise the beneficial changes and impacts resulting from EU law, as well as the importance of Euro-friendly interpretation of EU law by courts and of the (now predominantly extensive) national constitutional provisions that ensure openness to European and international law. European integration also entails valuable external mechanisms of control vis-à-vis national institutions, the need for which has been illustrated clearly e.g. by the developments towards an illiberal regime in Hungary and, since autumn 2015, in Poland. On the other hand, the increasing concerns with regard to governance at the EU level as well as the maturing of the EU legal order in general, make it the right time to consider a greater inclusion of perspectives that are more accommodating of national and comparative constitutional values and concerns, in a two-way ${ }^{80}$ or multi-directional, pluralist process. The national reports in the present book are an essential precondition for such a multi-directional process, as they provide a wider audience with an overview of national case law and constitutional debates, of which there has typically been little awareness in the mainstream English language European constitutional discourse. Indeed, a recent BBC article raised the question "[a]re we "losing knowledge" because of the growing dominance of English as the language of higher education and research? ${ }^{, 81}$

One could add that indirect mutualisation of debt liabilities through asset purchases by the European Central Bank programme and the need for a continued chain of democratic legitimacy between the people and the exercise of public power were also the underlying issues in the OMT case from the German Constitutional Court, BVerfG, case 2 BvR 2728/13 et al., OMT, order of 14 Jan. 2014, BVerfGE 134, 366.

${ }^{80}$ Mutanen 2015, pp. 387, 392-393.

${ }^{81}$ Pickles, M. (20 January 2016) Could the dominance of English harm global scholarship? BBC News. http://www.bbc.co.uk/news/business-35282235. 
Upon reading the national reports, the editors developed a sense that this concern is of direct relevance to constitutional law in terms of losing constitutional knowledge more generally. We even had a sense that perhaps national constitutions and national constitutional law are being displaced and written out of mainstream English language European constitutional narratives. Historical accounts have documented the considerable investment by the European Commission in founding specialised EU law journals and university centres, with the aim of shifting EU studies away from a comparative analysis of national laws (which would aim to identify common principles) to the study of the 'specificity' of EU law, focusing on the relationships between EU law (and the CJEU) and national law (and courts). ${ }^{82}$ On a broader level, Anne Lise Kjaer has raised a concern about the far-reaching impact of the changes in the discourse:

[W] hat will happen to the mutually divergent national languages and cultures of law when independency and autonomy of a common European law are presumed by an increasing number of European lawyers; when they accept the European Courts as legitimate interpreters of a supranational and transnational European law and involve themselves in an increasingly self-referential European legal discourse with lawyers from other European countries; and when communicating about law and speaking the law are no longer conducted in divergent national legal languages, but in a Europeanized legal language with no reference to the domestic laws of the Member States [emphasis added]. ${ }^{83}$

Sharing the broader concern expressed by Kjaer with regard to the disappearance of comparative law, the editors more specifically have a sense that in the quest for new epistemic communities to build the autonomous, self-referential and new constitutional order of the European Union, ${ }^{84}$ there is a substantial risk that some of the distinctively and uniquely valuable comparative European achievements in constitutionalism are being left behind and lost. Whilst this general impression had been based on reading mainstream English language European constitutional law literature, the Principal Investigator, since having started to write and present papers on the above topics, has been struck by the significant and growing number of researchers, doctoral students and even eminent, agenda-setting EU law scholars who have informally mentioned that they have never heard of what Pinelli above described as a continental European constitutional tradition that is predicated on post-totalitarian constitutional safeguards.

Thus, when taking a look at the national reports, the reader is invited to consider the broader question of what ought to be the direction of travel for national, comparative European, EU and global constitutionalism. Whilst 'EU', 'global' and 'post-national' constitutionalism may sound inherently more progressive, advanced and appealing, on a closer look they also entail an element of vagueness and even hollowness if compared e.g. to the post-totalitarian constitutional tradition

\footnotetext{
${ }^{82}$ Vauchez 2009, pp. 20-21.

${ }^{83}$ Kjaer 2015, p. 98.

${ }^{84}$ The shift from comparative European constitutional law to the autonomous EU constitutional law in the mainstream discourse has been explored and documented in greater detail in Albi 2015b, Sect. VIII.
} 
in continental Europe noted above, at the essence of which are extensive, precise, constitutionally codified and judicially protected fundamental rights and rule of law safeguards. There is a danger of conflating European constitutional law with EU constitutional law, which is in fact very different. The distinction, however, has increasingly become muddled and blurred. Indeed, in the large volume of books and articles written in this field, one can discern that the expression 'European Constitutional Law' has already predominantly come to denote EU constitutional law, often with no mention of Europe's national constitutions. Similarly, the term 'Europeanisation' has predominantly come to denote transition to autonomous EU law and to the EU governance model, rather than referring to the classic comparative European constitutional values.

The difference between EU constitutional law and continental European constitutional law has also been observed by a growing number of scholars. For example, Agustín Menéndez has pointed out that 'European legal studies have been very keen ... on conceptual innovation', which includes a switch to 'governance' amongst other concepts. He finds that it may be a suitable time to 'reconstruct European constitutional law with the help of "classical" democratic constitutional theory, as developed for decades in national Social and Democratic Rechtsstaats'. ${ }^{85}$ Menéndez regards 'the collective of national democratic constitutions' in Europe as '[t]he deep constitution of the European Union, the ultimate normative foundation of the whole edifice of the Union', rather than the EU Treaties. He finds that '[w]hen integration starts going against the key normative content of the national constitutions, it is time to start using such constitutions ... as the ultimate source of the yardstick of European constitutionality'. ${ }^{86}$ Nicola Lupo and Giovanni Piccirilli note the 'progressive decline of the formal categories that dominated the public law literature in the past two centuries' in the context of CJEU as well as ECHR case law. They highlight the risks to democracy, fundamental rights and to the legality principle, and express concern that there has been a shift towards the 'lowest common denominator' of the legality principle. ${ }^{87}$ Lupo and Piccirilli have put forward a plea that the parliamentary process in the first instance, and the ordinary and constitutional courts as a second step in the process, ought to promote and protect fundamental rights in order to restore the legality principle to its proper place'. ${ }^{88}$ In a similar vein, the Principal Investigator has elsewhere outlined the procedural, formal, thin nature of EU constitutionalism where the keywords are supremacy, uniformity, direct effect, autonomy, effectiveness and trust. She has propounded the concept of 'substantive co-operative constitutionalism', in which the aim would be to uphold the established standard of protection of fundamental rights, the rule of law and other constitutional values, and also to retain the

\footnotetext{
85 Menéndez 2014, p. 140.

${ }^{86}$ Menéndez 2013, pp. 525-526 (references omitted). Emphasis added.

${ }^{87}$ Lupo and Piccirilli 2015, pp. 55-56.

${ }^{88}$ Lupo and Piccirilli 2015, pp. 76-77.
} 
diversity of national constitutional orders. ${ }^{89}$ Jan Komárek has cautioned against transition to autonomous EU fundamental rights protection, especially in the Area of Freedom, Security and Justice, as EU constitutional law rests on the foundations of a market integration project and not on the post-war liberal constitutionalism that underlies Europe's national constitutions. ${ }^{90}$ Susana Galera has written that 'Europeans share a well-defined doctrine about the European understanding of rule-of-law requirements, initiated in 1949 by the Council of Europe', whereas in the EU context, 'persistent gaps in the EU judicial review system and the different understanding of what judicial independence or division of powers means ... represent a serious divergence affecting values and principles that have been applied for a long time on the European institutional scene'. 91 Amongst the national reports, the Italian report points out that the idea of constitutionalism propounded by leading international scholars 'does not readily correspond to what constitutional lawyers mean by the same word', and is 'conceived as an autonomous concept of international law rather than a concept derived by analogy from the domestic conception of constitutionalism'. ${ }^{92}$ The report underlines the importance of parallelism and axiological continuity between the values inspiring the domestic activity of the Italian Republic and those inspiring the external dimension (cf. the title 'The Constitution of Italy: Axiological Continuity between the Domestic and International Levels of Governance?').

It should be noted that another extensive part of the discourse associates European constitutionalism with the ECHR. Although the ECHR is beyond the scope of the present study, it is important to underline that the ECHR is regarded here, as explained above, as part of the well-established achievements of constitutionalism at the international level. Indeed, it emerges from the reports that the ECHR (and other international human rights treaties) has a constitutional status in the internal legal order in a large number of the countries studied, it is extensively and routinely referred to by the constitutional courts and other national courts, and the judgments of the European Court of Human Rights in Strasbourg (ECtHR) have widely had extensive rights-advancing, transformative effects. However, what is often overlooked is that the ECHR sets the minimum floor of protection for forty-seven countries in the wider European area, and the ECtHR grants the states a considerable margin of appreciation. Whilst the ECHR is the main domestic instrument of fundamental rights protection especially in several political/historical and traditional legal constitutional systems, in many others - especially among the post-totalitarian constitutional systems - the text of the constitution and the constitutional court have provided a higher and more extensive level of protection, also simply to a much greater range of fundamental

\footnotetext{
89 Albi 2015b, Sect. VIII ff.

${ }^{90}$ Komárek 2014, pp. 12-13, with references to further literature.

91 Galera 2010, p. 302.

92 The report on Italy by Martinico, Guastaferro and Pollicino in this book [The Constitution of Italy: Axiological Continuity Between the Domestic and International Levels of Governance?], Sect. 3.1.4, some references omitted. The changing vocabulary of constitutionalism is further explored in Martinico 2015. On this, see also references to national reports and literature supra in notes 5,74 and 75 . and the accompanying text.
} 
rights than those listed in the ECHR. By way of some typical examples, unlike most continental European systems, the ECHR does not require the adoption of a parliamentary statute for the limitation of fundamental rights, and it does not contain a list of social rights. Through EU law, however, the ECHR standard has in many areas become the maximum standard rather than the minimum floor.

In this context, the Comparative Study also seeks to draw attention to the centre-periphery dimension in the mainstream English language EU and transnational constitutional discourse. That is, the leading, influential, agenda-setting scholars and experts often come from what in terms of the scholarly discourse could be regarded as the 'centre' countries, many of which - especially the Netherlands, Belgium, the UK and Ireland - have a political/historical or traditional legal type of constitutional system, where fundamental rights protection is mainly based on the ECHR and the constitutional system is regarded as more pragmatic or 'efficacy'-oriented, as seen above. Additionally, considerable influence is held by US constitutional scholarship. Notably, in the euro crisis management, studies by economic actors have expressly called for political reform in 'political systems around the periphery' - especially Portugal, Spain, Italy and Greece - where the 'shortcomings' of the political and constitutional legacy include 'weak executives', 'constitutional protection of labour rights' and 'the right to protest'. 93

Whilst one limitation of the present book is its Euro-centric approach, the above questions are also more broadly relevant to what might be described as 'global constitutionalism' and 'global rule of law reform'. One of their elements is the above-mentioned shift to autonomous transnational and global standards and rules, with displacement of institutional accountability mechanisms as well as of standards of fundamental rights protection and constitutional review that have been established in traditional, state-based constitutionalism.

There is a further influence on the direction of travel that is relevant to global constitutionalism and global rule of law reform: the constitutional law of and constitutional thinking in the United States. The differences between the US and European (comparative) constitutionalism have been explored by leading comparative law scholars in a book edited by Georg Nolte under the auspices of the Venice Commission (the Council of Europe's Commission for Democracy through Law). ${ }^{94}$ Nolte observes that while focus during the Cold War era was on the similarities between US and European constitutional thought, in the present-day processes of globalisation and European constitutionalism - in the meaning of EU integration attention on their differences has gained in importance. EU constitutionalism, as Nolte notes, "seems to embody something which is both more removed from the "people" and more vague than national constitutional law', with clear-cut differences starting to

\footnotetext{
${ }^{93}$ Mackie et al. 2013, pp. 12-13. Emphasis added.

${ }^{94}$ Nolte 2003a.
} 
disappear and 'characteristic constitutionalisms' being transformed. ${ }^{95}$ Some concrete, profound differences between US and continental European constitutionalism include the following: the minimalistic approach to the role of the state and to fundamental and social rights in the US; the continuing debate in the US over the legitimacy of judicial review of legislation, which is known as the 'counter-majoritarian difficulty'; and the different approach to separation of powers, e.g. as regards the extensive role of independent agencies. ${ }^{96}$ Profound differences between the continental European tradition and US constitutionalism are found in the approach to courts and defence rights in criminal law and the understanding of human dignity, liberty, and the rule of law in this context. The continental European approach to constitutionalism and the rule of law places a strong emphasis on manifold safeguards for access to courts, and on the presumption of innocence and defence rights. By contrast, in the US, about $95 \%$ of criminal cases are resolved by the system of plea-bargaining, which entails out-of-court negotiations where there is no trial at all. This system has been explored in greater detail by Fair Trials International, which has expressed concern that the US has promoted the global spread of out-of-court plea-bargaining as part of the global rule of law reform. ${ }^{97}$

An understanding of the differences in the US constitutional system is crucial to the future direction of travel for European countries because the United States has become the main point of comparison for the EU constitutional order, and this has also impacted substantive European constitutional law. For example, in the Comparative Study, concern is expressed that through the EU mutual recognition system, the direction of travel has been towards removing judicial review in the country of residence in cross-border criminal as well as civil and administrative cases, and generally towards a more punitive and repressive criminal law. The Comparative Study also considers the influence of US thinking about state and social rights on the IMF and European Commission conditionality and austerity programmes. More broadly, we share the concern of Matej Avbelj that the dominant constitutional narrative, which equates the constitutionalisation of the EU with US-style federalism, has been transplanted in a misconceived way that is unsuited to the European constitutional landscape and may be a cause of the present malfunctioning of European integration. Hence, we support Avbelj's call that 'work must begin' on the EU's 'own, genuine and authentic constitutional theory' that would be oriented towards a pluralist legal entity with twenty-eight autonomous legal orders. ${ }^{98}$ Some scholars have overtly noted that the point of reference in the quality of constitutionalism today ought to be the

\footnotetext{
${ }^{95}$ Nolte 2003b, p. 10. Emphasis added.

${ }^{96}$ Some of these are outlined in contributions by different scholars to Nolte 2003a (especially Bognetti 2003). On the 'counter-majoritarian difficulty', see Somek 2014, pp. 15 et seq.

97 'Fair Trials to document the use and abuse of plea bargaining worldwide', 8 February 2016, https://www.fairtrials.org/fair-trials-to-document-the-use-and-abuse-of-plea-bargainingworldwide/; 'What is plea bargaining? A simple guide', 9 February 2016, https://www.fairtrials. org/what-is-plea-bargaining-a-simple-guide/.

98 Avbelj 2008, pp. 4 et seq., 15 et seq., 23, 24.
} 
German system rather than the American model, as is discussed more in the Comparative Study, with reference to literature collated by Alexander Somek, who sees constitutionalism as a project of emancipation. ${ }^{99}$ Further, Giovanni Bognetti, exploring human dignity, has noted a certain 'ruggedness' of the American system in comparison with the European systems, although he has observed that this ought to be balanced against other values, such as the greater individual initiative and competitiveness enabled by the US system. ${ }^{100}$

Against this background, for countries beyond the European area in search of good models for developing constitutionalism, awareness about some of the main differences between the EU, the ECHR, Europe's political/historical, traditional legal and post-totalitarian constitutional cultures, and US constitutional law is of direct practical importance for shaping discussion about what models might be considered as optimal. The present book, along with the Comparative Study, documents these differences in greater detail.

As a concluding note, we hope that the readers will appreciate the little known yet fascinating material in the national reports, which we consider to be of real practical importance, and that the edited volumes will make a contribution towards developing European constitutionalism in a way that would be better informed by comparative European constitutional law perspectives. We believe that the wealth of material, concerns and suggestions stemming from the national constitutional discourses in the Member States will prove to be a useful resource for national judges - as well as members of parliament, ombudspersons and other custodians of constitutional values - who might, in the light of the changes in the discourse described, be in doubt as to whether they should uphold the national constitution. In particular, we believe that in the dialogue with the European Court of Justice, national judges should not shy away from expounding a higher level of protection of fundamental rights or other constitutional values where these exist in national law. We hope that the wealth of bottom-up constitutionalism on display in these two volumes will give them the confidence to do so. It is our aspiration that scholars in constitutional and public law who have a long and proud tradition in Europe as custodes over the exercise of public authority - will perceive this book as confirmation that their vigilance can and ought to continue when public power is transferred to new sites of authority and veiled in new legal orders. Recognition that colleagues in other Member States have similar fears about strains on constitutional values, and the solutions adopted, may provide new vigour for constitutionalism in Europe.

Last but not least, we believe that the present volumes will also be of interest to the judges of the European Court of Justice and the lawyers of the institutions of the EU. In fulfilling their mission to create, interpret and advance European Union law, we hope that they will find inspiration in this comprehensive study that brings together the research of over sixty experts from throughout the Union, highlighting

\footnotetext{
${ }^{99}$ Somek 2014, p. 10 (emancipation of constitutionalism) and pp. 85-86 footnotes 38 and 42 (summary of writings of authors comparing German and US constitutionalism).

${ }^{100}$ Bognetti 2003, p. 78.
} 
the constitutional traditions common to these European states as well as important elements of diversity that derive from the historical evolution and unique equilibrium of the individual constitutional systems in Europe.

As the book is going to press, we have decided to add the following final observation. In the time after the material for the book was completed, there has been a widespread surge of illiberal and extremist, right-wing political forces across Europe and beyond, and thus the protection of the comparative European constitutional values and achievements has become more difficult. Regrettably, there is a risk that these values may be conflated with general protection of nationalism or populism and dismissed offhand. However, it is hoped that - when looking through the national reports - the reader will agree that there has been a structural oversight, in that advanced comparative European constitutional values and achievements have unduly been left out of the transnational discourse, and that it is important for this omission to be corrected by the mainstream scholarly, political and legal communities, in order to avoid it happening that the protection of these values will be misused by and/or associated with extremist movements.

\section{References}

Albi A. (2015a) Erosion of Constitutional Rights in EU Law: A Call for 'Substantive Co-Operative Constitutionalism' Part 1. Vienna J of International Constitutional L 9: 151-185. Available Open Access at http://ssrn.com/abstract=2746522.

Albi A. (2015b) Erosion of Constitutional Rights in EU Law: A Call for 'Substantive Co-Operative Constitutionalism' Part 2. Vienna J of International Constitutional L 9:291-343. Available Open Access at http://ssrn.com/abstract=2741623.

Avbelj M. (2008) The Pitfalls of (Comparative) Constitutionalism for European Integration. Eric Stein Working Paper 1/2008. http://www.ericsteinpapers.cz/.

Beck G. (2012) The Legal Reasoning of the Court of Justice of the EU. Hart, Oxford.

Besselink L. (2006) The Dutch Constitution, the European Constitution and the Referendum in the Netherlands. In Albi A., Ziller J. (eds.) The European Constitution and National Constitutions: Ratification and Beyond. Kluwer, Alphen aan den Rijn, pp. 113-123.

Blekxtoon R. (ed.) (2005) Handbook on the European Arrest Warrant. T.M.C. Asser Press, The Hague.

Blekxtoon, R. (2009) Foreword. In: Keijzer N., van Sliedregt E. (eds.) The European Arrest Warrant in Practice. T.M.C. Asser Press, The Hague, pp. V-VI.

Bobek M. (2014) The Legal Reasoning of the Court of Justice of the EU. ELR 39:418-428.

Bognetti G. (2003) The Concept of Human Dignity in European and U.S. Constitutionalism. In: Nolte G. (ed.) European and U.S. Constitutionalism. European Commission for Democracy Through Law (Venice Commission) CDL-STD(2003)037, pp. 65-80. http://www.venice.coe. int/webforms/documents/default.aspx?pdffile=CDL-STD(2003)037-e.

Bouza Garcia L. (2017) The "New Narrative Project" and the politicisation of the EU. Journal of Contemporary European Studies 25(3):340-353.

Coppel J., O'Neill A. (1992) The European Court of Justice: Taking Rights Seriously? CML Rev. 29(4):669-692.

De Búrca G. (2005) Rethinking Law in Neofunctionalist Theory. Journal of European Public Policy 12(2):310-326. 
De Visser M. (2014) Constitutional Review in Europe. A Comparative Analysis. Hart Publishing, Oxford.

Dobner P., Loughlin M. (2010) Introduction. In: Dobner P., Loughlin M. (eds.) The Twilight of Constitutionalism? Oxford University Press, Oxford, pp. xi-xvi.

Erbežnik A. (2014) Mutual Recognition in EU Criminal Law and Its Effects on the Role of a National Judge. In: Peršak N. (ed.) Legitimacy and Trust in Criminal Law, Policy and Justice Norms, Procedures, Outcomes. Ashgate Publishing Limited, Farnham, pp. 131-152.

Galera S. (2010) The European Contribution to an emerging global law. In Galera S. (ed.) Judicial Review: A Comparative Analysis Inside the European Legal System. Council of Europe, Strasbourg, pp. 301-308.

Grimm, D. (2012) Types of Constitutions. In. Rosenfeld M., Sajó A. (eds.) The Oxford Handbook of Comparative Constitutional Law. OUP, Oxford, pp. 98-132.

Harlow C. (2006) Global Administrative Law: The Quest for Principles and Values. EJIL 17:187214.

Herlin-Karnell E. (2007) In the Wake of Pupino: Advocaten voor de Wereld and dell'Orto. German Law Journal 8(12):1147-1161.

Hogan G. (2014) The Influence of the continental constitutional tradition on the drafting of the Constitution. In: Ruane B., Barniville D., O'Callaghan J. (eds.) Law and Government: A Tribute to Rory Brady. Round Hall, Dublin, pp. 162-164.

Joerges C. (2014) Three Transformations of Europe and the Search for a Way Out of its Crisis. In: Joerges C., Glinski C. (eds.) The European Crisis and the Transformation of Transnational Governance. Authoritarian Managerialism versus Democratic Governance. Hart, Oxford and Portland, pp. 25-46.

Joerges C., Weimer M. (2012) A Crisis of Executive Managerialism in the EU: No Alternative? Maastricht Working Paper 2012-7. http://www.maastrichtuniversity.nl/web/Faculties/FL/ 2012_maastricht_working_papers.htm.

Kjaer A. (2015) Theoretical Aspects of Legal Translation in the EU: The Paradoxical Relationship between Language, Translation and the Autonomy of EU Law. In Šarčević S. (ed.) Language and Culture in EU Law. Multidisciplinary Perspectives. Ashgate, London and New York, pp. 91-108.

Kellermann A., De Zwaan J.W., Czuczai J. (eds.) (2001) The Constitutional Impact of EU Enlargement at EU and National Level. T.M.C. Asser Press, The Hague.

Komárek J. (2014) Why National Constitutional Courts Should Not Embrace EU Fundamental Rights, LSE Law, Society and Economy Working Papers 23/2014, http://eprints.lse.ac.uk/ 60568/1/WPS2014-10_Komarek.pdf.

Krisch N. (2010) Beyond Constitutionalism: The Pluralist Structure of Postnational Law. Oxford University Press, Oxford.

Kuo M.-S. (2010) The end of constitutionalism as we know it? Boundaries and the State of Global Constitutional (Dis)ordering. Transnational Legal Theory 1:329-369.

Lupo N., Piccirilli G. (2015) The Relocation of the Legality Principle by the European Courts. Case Law: An Italian Perspective. EuConst 11(1):55-77.

Mackie, D., Barr M. et al. (2013) Euro Area Adjustment: About Half-way There, by J.P. Morgan Bank, Europe Economic Research 28 May 2013, http://www.europe-solidarity.eu/documents/ ES1_euro-area-adjustment.pdf.

Martinico G. (2015) Constitutionalism, Resistance and Openness: Comparative Law Reflections on Constitutionalism in Global Governance. STALS (Sant'Anna Legal Studies, Pisa) Research Paper No 5/2015. http://www.stals.sssup.it/files/martinicoSTALS.pdf. A modified version published as Martinico G. (2016) Constitutionalism, Resistance, and Openness: Comparative Law Reflections on Constitutionalism in Postnational Governance. YEL 35:318-340.

Mendes J. (2014) Rule of law and participation: A Normative analysis of internationalized rulemaking as composite procedures. ICON 12(2):370-401.

Menéndez A.J. (2013) The Existential Crisis of the European Union. German Law Journal 14:453-526.

Menéndez A.J. (2014) Editorial: A European Union in Constitutional Mutation? ELJ 20:127-141. 
Mutanen A. (2015) Towards A Pluralistic Constitutional Understanding of State Sovereignty in the European Union? The Concept, Regulation and Constitutional Practice of Sovereignty in Finland and Certain Other EU Member States. Ph.D. thesis, University of Helsinki.

Nolte G. (ed.) (2003a) European and U.S. Constitutionalism. European Commission for Democracy Through Law (Venice Commission) CDL-STD(2003)037. http://www.venice. coe.int/webforms/documents/default.aspx?pdffile=CDL-STD(2003)037-e; also published as Nolte G. (ed.) (2003) European and US Constitutionalism. CUP, Cambridge.

Nolte G. (2003b), Introduction - European and U.S. Constitutionalism: Comparing Essential Elements. Nolte G. (ed.) (2003) European and U.S. Constitutionalism. European Commission for Democracy Through Law (Venice Commission) CDL-STD(2003)037, pp. 9-22. http:// www.venice.coe.int/webforms/documents/default.aspx?pdffile=CDL-STD(2003)037-e.

Pinelli C. (2016) The Formation of a Constitutional Tradition in Continental Europe since World War II. EPL 22:257-268.

Popelier P. (2014) Europe clauses and constitutional strategies in the face of multilevel governance. Maastricht Journal of European and Comparative Law 21:300-319.

Schünemann B. (2007) Alternative-Project for a European criminal law and procedure. Criminal Law Forum 18(2):227-251.

Simoncini A. (2013) Back to "Flexible" Constitutions? The Impact of Financial Crisis and the Decline of the European Constitutionalism. Italian Journal of Public Law 5(2):157-187.

Somek A. (2014) The Cosmopolitan Constitution. OUP, Oxford.

Sweet A.S. (2012) Neofunctionalism and Supranational Governance (unabridged version). Faculty Scholarship Series, Paper 4628, http://digitalcommons.law.yale.edu/cgi/viewcontent.cgi? article $=5636 \&$ context $=$ fss_papers.

Sweet A.S., Brunell T. (2013) Trustee Courts and the Judicialization of International Regimes: The Politics of Majoritarian Activism in the ECHR, the EU, and the WTO. Journal of Law and Courts 1(1):61-88. http://digitalcommons.law.yale.edu/fss_papers/4625/.

Vauchez A. (2009) The transnational politics of judicialization. Van Gend en Loos and the making of the EU polity. ELJ 16:1-28.

Walsh D.P.J. (2009) The European Arrest Warrant in Ireland: Surrendering Our Standards to a European Criminal Law Area. In: Bacik I.C., Heffernan L. (eds.) Criminal Law and Procedure: Current Issues and Emerging Trends. First Law, Dublin, pp. 5-34.

Wilkinson M. (2016) The Reconstitution of Postwar Europe: Lineages of Authoritarian Liberalism. LSE working paper 5/2016. http://www.lse.ac.uk/law/working-paper-series.

Zumbansen, P. (2012) Comparative, global and transnational constitutionalism: The emergence of a transnational legal-pluralist order. Global Constitutionalism 1(1):16-52.

Open Access This chapter is licensed under the terms of the Creative Commons Attribution 4.0 International License (http://creativecommons.org/licenses/by/4.0/), which permits use, sharing, adaptation, distribution and reproduction in any medium or format, as long as you give appropriate credit to the original author(s) and the source, provide a link to the Creative Commons license and indicate if changes were made.

The images or other third party material in this chapter are included in the chapter's Creative Commons license, unless indicated otherwise in a credit line to the material. If material is not included in the chapter's Creative Commons license and your intended use is not permitted by statutory regulation or exceeds the permitted use, you will need to obtain permission directly from the copyright holder. 